\title{
XANTHOGRANULOMATOUS APPENDICITIS- AN UNCOMMON ENTITY
}

\author{
Sunita Hoabam 1 , Kh. Sunitarani Devi², Urmila Thiyam ${ }^{3}$, L. Radita 4 , Deepa Longjam ${ }^{5}$
}

${ }^{1}$ Associate Professor, Department of Pathology, JNIMS, Imphal.

${ }^{2}$ Postgraduate Student, Department of Pathology, JNIMS, Imphal.

${ }^{3}$ Assistant Professor, Department of Pathology, JNIMS, Imphal.

${ }^{4}$ Senior Pathologist, Department of Pathology, JNIMS, Imphal.

${ }^{5}$ Assistant Professor, Department of Pathology, JNIMS, Imphal.

\section{ABSTRACT}

\section{BACKGROUND}

Xanthogranulomatous inflammation is a clinical finding described commonly in kidney and gallbladder, but xanthogranulomatous appendicitis is rare and very few cases have been reported so far. We report a case of a 56-year-old lady who presented with acute pain in Rt lower quadrant of abdomen along with nausea. Ultrasonography was inconclusive and with clinical impression of acute appendicitis, the patient underwent appendicectomy. Histologically, a diagnosis of xanthogranulomatous appendicitis was made.

\section{KEYWORDS}

Appendicitis, Histiocytes, Xanthoma.

HOW TO CITE THIS ARTICLE: Hoabam S, Devi KS, Thiyam U, et al. Xanthogranulomatous appendicitis- An uncommon entity. J. Evolution Med. Dent. Sci. 2017;6(13):1061-1063, DOI: 10.14260/Jemds/2017/229

\section{BACKGROUND}

Xanthogranulomatous inflammation is a rare form of chronic inflammation that can involve various organs but is most commonly reported in the kidney and gallbladder. ${ }^{1}$ Histologically, it is characterised by presence of large number of foamy histiocytes admixed with lymphocytes and plasma cells. ${ }^{2}$ Xanthogranulomatous inflammation of appendix is a rare phenomenon and few cases have been reported in literature.1,3,4 In view of the rarity of this condition, we report a case of XA in a 56-year-old lady who presented with acute pain abdomen and nausea.

\section{Case Report}

A 56-year-old lady presented with complaints of acute pain in right lower quadrant of abdomen with nausea. On clinical examination, she was found to have tenderness in the McBurney's point along with rebound tenderness. There was no history of fever. Her ultrasonography was inconclusive. Routine blood test showed a white blood count of 14,000 cells/cu mm with $81 \%$ neutrophils, $\mathrm{Hb} 11.5 \mathrm{~g} / \mathrm{dL}$, platelet count 1.8 lakhs $/ \mathrm{mm}^{3}$ and an increased ESR level (32 $\mathrm{mm} /$ hour). Even though the ultrasonography report was inconclusive based on the clinical findings and blood report, she was clinically diagnosed as a case of acute appendicitis and an appendicectomy was performed. Per operatively the appendix was inflamed and did not show any gangrenous change or perforation. We received a specimen of appendix which measured $7 \mathrm{~cm}$ in length and $1 \mathrm{~cm}$ in diameter. The external surface appeared congested and dull. Cut surface showed presence of focal yellow coloured areas and congested mucosa. The lumen contained faecolith. The Haematoxylin and Eosin stained sections from the

Financial or Other, Competing Interest: None.

Submission 04-01-2017, Peer Review 01-02-2017,

Acceptance 06-02-2017, Published 13-02-2017.

Corresponding Author:

Dr. Kh. Sunitarani Devi,

Thangmeiband Hijam Leikai,

Imphal, Manipur-795004.

E-mail: sunitarani.kh@gmail.com

DOI: $10.14260 /$ jemds $/ 2017 / 229$

\section{(c) (i) $\odot$}

appendicectomy specimen showed patchy neutrophilic infiltration of mucosa and clusters of foamy histiocytes (Figure 1) along with foreign body type multinucleated giant cells, lymphocytes and plasma cells in the muscular and serosal layers (Figure 2). No epithelioid granulomas or Michaelis-Gutmann bodies were noted which rules out the possibility of Crohn's disease or malakoplakia. A diagnosis of xanthogranulomatous appendicitis was made.

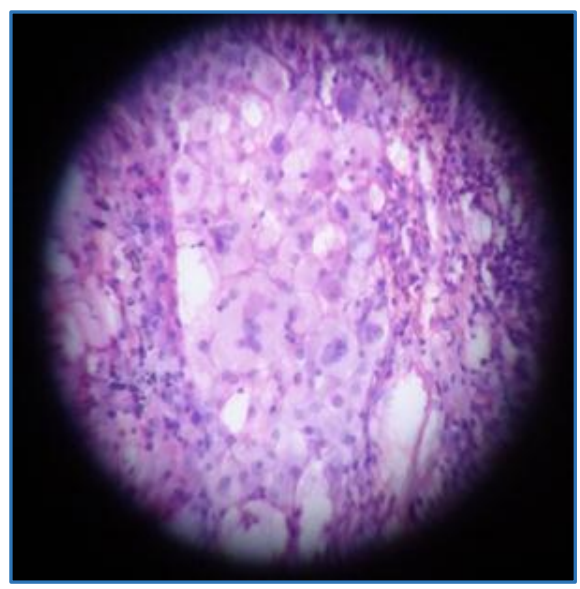

Figure 1. H\&E stained section of appendix showing focus of xanthogranulomatous inflammation with xanthoma cells and chronic inflammatory cells

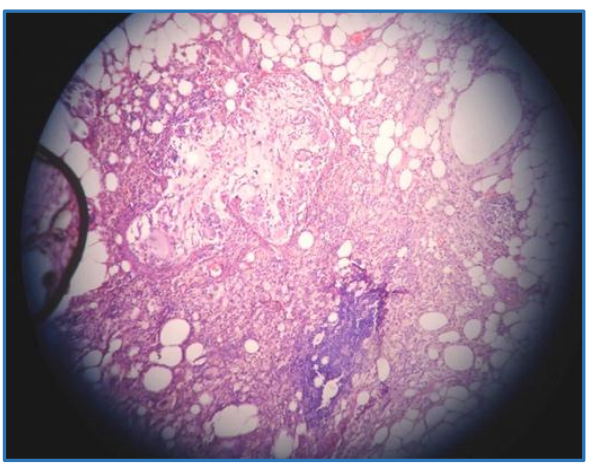

Figure 2. H\&E stained section of appendix on low power view of numerous giant cells and chronic inflammatory cells 


\section{DISCUSSION}

Xanthogranulomatous inflammation is a rare form of chronic inflammation. Although it is commonly described in various organs such as kidney and gallbladder, xanthogranulomatous appendicitis is a rare phenomenon. ${ }^{1}$ Osterlind initially described xanthogranulomatous inflammation in the kidney in $1944 . .^{5}$ Birch et al published the first reported cases of XA in $1993 .{ }^{6}$ After a year later, McVey et al added another case of XA to the literature. ${ }^{7}$ An association of xanthogranulomatous response with longstanding appendiceal inflammation and the formation of appendiceal mass was suggested by both the authors. Few cases of involvement of appendix by xanthogranulomatous inflammation has been reported in literature.1,3,4 Besides these two common sites it has also been reported in other organs as endometrium, fallopian tubes and sigmoid colon.8,9

Xanthogranulomatous inflammation affects women more frequently than men with a variable age of presentation. This finding has been reflected in various series ${ }^{10,11}$ and till date majority of the case reports of XA published have been females. Histologically, it is manifested by collection of lipid laden macrophages admixed with mixed inflammatory infiltrate composed of lymphocytes, plasma cells, neutrophils and multinucleated giant cells with or without cholesterol clefts. 12

The pathogenesis of xanthogranulomatous inflammation is unknown but some of the proposed aetiologies suggest a chronic inflammatory process which results in tissue destruction and localised proliferation of lipid containing macrophages. ${ }^{2}$ Munichor et al suggested that a defective lipid transport, immunologic disturbances and infection by low virulence organisms and lymphatic obstruction may be the underlying pathogenic mechanism. ${ }^{4} \mathrm{He}$ examined the specimen of appendix under electron microscopy and showed the presence of electron-lucent lipid droplets of variable sizes in the xanthoma cells and in other cells as well.

Xanthogranulomatous inflammation (XGI) may also present with mass like lesion and cause destruction of the organ involved thus mimicking an invasive cancerous lesion. ${ }^{1,13}$ This was shown in a case reported by Chuang et al who reported a case of a 39-year-old man who presented with fever, lower abdominal pain and mass in right iliac fossa. With the impression of cancer hemicolectomy was done. The histological examination revealed it as XA. ${ }^{1}$

When XGI presents as a mass with extension of fibrosis and inflammation to surrounding tissues, it is very difficult to differentiate it from advanced cancer or a local abscessed intestinal mass. ${ }^{14}$

Radiological diagnosis of XGI using USG and CT is challenging. Contrast-enhanced USG using Sonazoid contrast enhancing agent has increased the diagnostic accuracy in differentiating chronic inflamed gall bladder from a malignant lesion. ${ }^{15}$ This explains the inconclusive USG report in our case which would have been precise if contrast enhancement was done.

Recently Kaushik et al have published a case report where they have highlighted the usefulness of an intraoperative imprint cytology for quick diagnosis to decipher the cause of the mass lesion so as to avoid extensive resection. 16
The classic microscopic appearance of XA display presence of numerous lipid laden histiocytes, abundant hemosiderin, multinucleated giant cells admixed with cholesterol clefts and mixed inflammatory infiltrate composed of polymorphs, lymphocytes and plasma cells. ${ }^{17}$

Guo and Greenson noted a higher incidence of XA in interval appendectomies as compared to control group of patients who had acute appendicitis and underwent routine appendectomy. 18

\section{CONCLUSION}

Xanthogranulomatous appendicitis is a rare clinical entity which might present with varied clinical presentation of acute or subacute abdominal pain or sometimes as a mass lesion which might lead to radical resection.

\section{REFERENCES}

[1] Chuang YF, Cheng TI, Soong TC, et al. Xanthogranulomatous appendicitis. J Formos Med Assoc 2005;104(10):752-4.

[2] Peterson RO. Kidney. In: Peterson RO. (eds). Urologic pathology. Chap 6. Philadelphia: JB Lippincott 1986:40-6.

[3] Singh V, John KM, Malik A, et al. Xanthogranulomatous appendicitis: uncommon histologic variant of a common entity. Medical J Armed Forces India 2013:13.

[4] Munichor M, Kerner H, Cohen $H$, et al. Xanthogranulomatous appendicitis-an incidental finding of localized pathology. Ultrastruct Pathol 2000;24(1):33-9.

[5] Osterlind S. Uber: pyelonephritis xanthomatosa. Acta Chirurgica Scandinavica 1944;90:369-76.

[6] Birch PJ, Richmond I, Bennett MK. Xanthogranulomatous appendicitis. Histopathology 1993;22(6):597-8.

[7] McVey RJ, McMohan RF. Xanthogranulomatous appendicitis. Histopathology 1994;24(2):198.

[8] Gray Y, Libbey NP. Xanthogranulomatous salpingitis and oophoritis: a case report and review of the literature. Arch Pathol Lab Med 2001;125(2):260-3.

[9] Oh YH, Seong SS, Jang KS, et al. Xanthogranulomatous inflammation presenting as a submucosal mass of the sigmoid colon. Pathol Int 2005;55(7):440-4.

[10] Malek RS, Elder JS. Xanthogranulomatous pyelonephritis: a critical analysis of 26 cases and of the literature. J Urol 1978;119(5):589-93.

[11] Parsons MA, Harris SC, Longstaff AJ, et al. Xanthogranulomatous pyelonephritis: a pathological clinical and aetiological analysis of 87 cases. Diagn Histopathol 1983;6(3-4):203-19.

[12] Cozzutto C, Carbone A. The xanthogranulomatous process. Xanthogranulomatous inflammation. Pathol Res Pract 1988;183(4):395-402.

[13] Maeda T, Shimada M, Matsumata $T$, et al. Xanthogranulomatous cholecystitis masquerading as gallbladder carcinoma. Am J Gastroenterol 1994;89(4):628-30. 
[14] Chieco PA, Antolino L, Giaccaglia V, et al. Acute abdomen: rare and unusual presentation of right colic xanthogranulomatosis. World J Gastroenterol 2014;20(26):8717-21.

[15] Ueda J, Yoshida H, Arima Y, et al. A rare case of xanthogranulomatous cholecystitis preoperatively diagnosed with contrast-enhanced ultrasonography. J Nippon Med Sch 2011;78:194-8.

[16] Kaushik R, Gulati A, Vedant D, et al. Cytological diagnosis of xanthogranulomatous appendicitis. J Cytol 2017;34(1):48-50.
[17] Daniels J, Montgomery E. Inflammatory disorders of the appendix, in surgical pathology of the GI tract, liver, biliary tract, and pancreas. $2^{\text {nd }}$ edn. Odze RD, Goldblum JR. (eds). Saunders, Philadelphia, Pa, USA, 2009:395-404.

[18] Guo G, Greenson JK. Histopathology of interval (delayed) appendectomy specimens: strong association with granulomatous and xanthogranulomatous appendicitis. Am J Surg Pathol 2003;27(8):1147-51. 